INTERNATIONAL BULLETIN OF BACTERIOLOGICAL
NOMENCLATURE AND TAXONOMY
$\begin{array}{llll}\text { Volume } 10 & \text { No. } 3 & \text { July } 15,1960 & \text { pp. } 223-230\end{array}$

\title{
THE DIFFERENTIATION OF AEROMONAS AND C27 CULTURES FROM ENTEROBACT ERIACEAE
}

\author{
W.H. Ewing and Jane G. Johnson \\ Communicable Disease Center \\ Public Health Service, U.S. Department \\ of Health, Education, and Welfare, \\ Atlanta, Georgia
}

The reactions given by cultures of Aeromonas in the biochemical tests commonly used in the diagnostic laboratory often resemble those of Enterobacteriaceae and the differentiation of Aeromonas may be difficult. Frequently, however, strains of Aeromonas can be identified accurately if a number of media are employed and if the reactions obtained are compared with those given by members of the various groups of Enterobacteriaceae. Also, flagellar stains are of assistance in this differentiation.

In a search for a more rapid, as well as accurate, method of distinguishing Aeromonas cultures, we tried the cytochrome oxidase test employed by Gaby and Hadley (1957) for the identification of Pseudomonas aeruginosa. The test media employed by these investigators were nutrient broth tubed in $4.5 \mathrm{ml}$ amounts and nutrient agar or blood agar plates. Cultures to be tested were incubated for 18 to 24 hours at $37^{\circ} \mathrm{C}$ or at room temperature $\left(24\right.$ to $\left.28^{\circ} \mathrm{C}\right)$, depending upon which was optimal. Following incubation, $0.2 \mathrm{ml}$ of a 1.0 per cent solution of alpha-naphthol in 95 per cent ethyl alcohol and $0.3 \mathrm{ml}$ of a 1.0 per cent aqueous solution of para-aminodimethylaniline oxalate were added to each broth culture. The cultures were then shaken. The appearance of a blue color was indicative of the presence of cytochrome oxidase. Plate cultures were tested by allowing a few drops of an equal-parts mixture of the two reagents to flow over isolated colonies.

The authors first employed the method as described above but subsequent tests indicated that nutient broth tubed in $1.0 \mathrm{ml}$ amounts gave results comparable to those obtained with larger volumes and long nutrient agar slants yielded superior results. Hence, nutrient agar slant cultures, incubated at $37^{\circ} \mathrm{C}$, or at a lower temperature if required, for 18 to 20 hours were employed in the present studies. After 
incubation, two or three drops of each reagent were introduced and the tubes were tilted so that the reagents were mixed and flowed over the growth on the slants. Positive results were indicated by the development of an intense blue color in the growth within 30 seconds. Occasional cultures required up to one minute to give intense reactions. Rare strains required up to two minutes and produced less intense or spotty reactions. Any doubtful or very weak reaction that occurred after two minutes was ignored.

The results of cytochrome oxidase tests with cultures representative of the various groups of Enterobacteriaceae, with Aeromonas, and Aeromonas-like strains, as well as with members of several other bacterial groups, are given in Table 1. While none of the Enterobacteriaceae tested gave even a weakly positive reaction, all of the strains of Aeromonas, Aeromonas-1ike organisms (C27), Yibrio, and Pseudomonas reacted rapidly with the production of an intense blue color. Although only a very few cultures of Alcaligenes were tested, all were positive within 30 seconds. Conversely, the small number of strains of Xanthomonas tested were negative. After most of the work reported was completed, the authors came upon the work of Griffin et al. (1952, 1953) in which it was reported that cultures of Aeromonas salmonicida were oxidase positive. However, this was the only reference found to the use of the test with Aeromonas and we found no reference to its use with Vibrio comma or other vibrios.

The biochemical and serological reactions of 40 Aeromonas and 48 C27 ( $\mathrm{v}$. inf.) strains were studied in $\overline{\text { detail }}$ and the results will be reported elsewhere. However, tests that proved to be of particular value in the differentiation of strains of Aeromonas and of Aeromonas-like cultures and those of the Enterobacteriaceae with which they are more likely to be confused, are summarized in Tables 2 and 3 . Attention is directed to the value of the decarboxylase tests in effecting this differentiation. The majority of the Aeromonas cultures were negative in lysine medium, strongly positive in arginine, and negative in ornithine medium. This pattern of reaction was particularly valuable in the differentiation of Aeromonas and the Enterobacteriaceae. Among the latter, only Citrobacter strains reacted in a similar manner and in that instance the reactions in arginine medium were delayed 2 or 3 days and were less intense 
BACTERIOLOGICAL NOMENCLATURE

AND TAXONOMY

Table 1. Results of Cytochrome Oxidase Tests

$$
\text { Enterobacteriaceae (1222 cultures) }
$$

\begin{tabular}{lccc}
\hline & $\begin{array}{c}\text { No. } \\
\text { Tested }\end{array}$ & $\begin{array}{c}\text { No. } \\
+\end{array}$ & $\begin{array}{c}\text { No. } \\
-\end{array}$ \\
\hline Escherichia & 222 & 0 & 222 \\
Shigella & 152 & 0 & 152 \\
Salmonella & 102 & 0 & 102 \\
Arizona & 61 & 0 & 61 \\
Citrobacter & 108 & 0 & 108 \\
Klebsiella & & & \\
Aerobacter & 54 & 0 & 54 \\
Hafnia & 144 & 0 & 144 \\
Serratia & 56 & 0 & 56 \\
Proteus & 79 & 0 & 79 \\
Providence & 134 & 0 & 134 \\
\hline
\end{tabular}

Aeromonas, Vibrio, etc. (279 cultures)

Aeromonas species

C27

Vibrio comma

Vibrio species

Pseudomonas species

Xanthomonas species

Alcaligenes species

Flavobacterium species

Enwinia species

$\begin{array}{rrr}36 & 36 & 0 \\ 48 & 48 & 0 \\ 115 & 115 & 0 \\ 12 & 12 & 0 \\ 15 & 15 & 0 \\ 4 & 0 & 4 \\ 5 & 5 & 0 \\ 10 & 2 * & 8 \\ 34 & 3 * & 31\end{array}$

*These reactions were weak and slow.

than those given by Aeromonas (Ewing, Davis, and Edwards, in press).

The differential reactions of 48 strains of an Aeromonaslike biotype (C27) are summarized in Table 3, along with those given by Aeromonas formicans, Aeromonas salmonicida, and some Enterobacteriaceae for which they may be 
Page 226

INTERNATIONAL BULLETIN

Table 2. Differentiation of Aeromonas (Based on the Reactions given by the Majority of Cultures)

\begin{tabular}{|c|c|c|c|c|c|}
\hline & \multirow[b]{2}{*}{ Serratia } & \multicolumn{2}{|c|}{ Aerobacter } & \multirow{2}{*}{$\frac{\text { Klebsiella }}{\text { oxytoca }}$} & \multirow[b]{2}{*}{ Aeromona 8** } \\
\hline & & $C^{*}$ & Hafnia & & \\
\hline Gas from glucose & $\mathrm{d}$ & + & + & + & $\mathrm{d}$ \\
\hline Arabinose & - & + & + & + & tor - \\
\hline Inositol & $t$ or $(t)$ & + & - & + & - \\
\hline Rhamnose & - & - & + & + & - \\
\hline Xylose & $d$ & + & + & + & - \\
\hline Raffinose & - & + & - & & - \\
\hline Sorbitol & + & + & - & + & - \\
\hline Dulcitol & - & - & - & $d$ & - \\
\hline Adonitol & $t$ or $(t)$ & - & - & + & - \\
\hline Indol & - & - & - & + & + or - \\
\hline MR 37C & - & d & + & - & + \\
\hline $22 \mathrm{C}$ & - & - & - & - & $d$ \\
\hline VP $37 \mathrm{C}$ & + & d & $\mathrm{d}$ & + & d \\
\hline $22 \mathrm{C}$ & + & + & + & + & $d$ \\
\hline $\begin{array}{l}\text { Lysine } \\
\text { decarboxylase }\end{array}$ & + & $t \operatorname{or}(t)$ & + & + & - \\
\hline $\begin{array}{l}\text { Arginine } \\
\text { dihydrolase }\end{array}$ & - & - & - & - & + \\
\hline $\begin{array}{l}\text { Ornithine } \\
\text { decarboxylase }\end{array}$ & + & + & + & - & - \\
\hline Gelatin & + & + & - & + & $t$ or $(t)$ \\
\hline $\begin{array}{l}\text { Cytochrome } \\
\text { oxidase test }\end{array}$ & - & - & - & - & + \\
\hline
\end{tabular}

+ positive in 1 or 2 days.

$(+)$ delayed positive.

+ or - majority of strains positive, negative varieties occur.

d different biochemical types $(t,(t)$, or -$)$.

* Aerobacter subgroup C corresponds to $\underline{A}$. liquefaciens (Grimes).

* Forty cultures, including A. formicans, A. salmonicida, and other described species. 
BACTERIOLOGICAL NOMENCLATURE AND TAXONOMY

Table 3. Differentiation of Aeromona s, C27, etc.

\begin{tabular}{|c|c|c|c|c|c|c|}
\hline & $\stackrel{\text { A. }}{\text { salmonicida }}$ & $\stackrel{\text { A. }}{\text { formicans }}$ & $\mathrm{C} 27$ & $\begin{array}{l}\text { Shigella } \\
\text { sonnei }\end{array}$ & $\frac{E}{01} \cdot \frac{c o l i}{12 a, c}$ & $\underset{\text { coli }}{\underline{E} .}$ \\
\hline Gas from glucose & - & - & - & - & - & $+(-)$ \\
\hline Mannitol & + & + & - & + & - & + \\
\hline Dulcitol & - & - & - & - & $(t)$ & d \\
\hline Rhamnose & - & - & - & $t$ or $(t)$ & + & + \\
\hline Arabinose & $(+)$ & + & - & + & + & + \\
\hline Inositol & - & - & + & - & - & - \\
\hline Xylose & - & - & - & - & - & + \\
\hline Raffinose & - & - & - & $t$ or $(+)$ & + & d \\
\hline Sorbitol & - & - & - & - & + & + \\
\hline Salicin & + or $(+) *$ & + & $(+)$ or - & - & d & d \\
\hline Indol & - & t or - & + & - & + & + \\
\hline Simmons' citrate & - & + or $(+)$ & - & - & - & - \\
\hline Gelatin & + & $t^{3}$ & - & - & - & _- \\
\hline $\mathrm{KCN}$ & - & + & - & - & - & - \\
\hline Mucate & - & - & - & - & + & + \\
\hline \multirow{2}{*}{$\begin{array}{l}\text { Lysine } \\
\text { decarboxylase } \\
\text { Arginine } \\
\text { dihydrolase }\end{array}$} & - & - & + & - & - & d \\
\hline & - & + & + & - or $(t)$ & $-\operatorname{or}(t)$ & d \\
\hline \multirow{2}{*}{$\begin{array}{l}\text { Ornithine } \\
\text { decarboxylase } \\
\text { Cytochrome } \\
\text { oxidase test }\end{array}$} & - & - & $\mathrm{d}$ & + & - & $d$ \\
\hline & + & + & + & - & - & _- \\
\hline
\end{tabular}

*Gas formed slowly from salicin. 
mistaken. The resemblance of the C27 strains to Shigella sonnei was superficial but the reactions of the latter were included for comparative purposes. Seventy strains of the C27 biotype were collected and studied at intervals during the past 16 years by the senior author. Of these 48 were available for the work reported here as well as for more detailed studies to be reported elsewhere. Ferguson and Henderson (1947) apparently gave the first description of this microorganism, to which they applied the designation C27. These investigatiors reported that the flagellation of the microorganism was amphitrichous. Further, they demonstrated that the $O$ antigens of the $C 27$ strain were identical with those of $S$. sonnei form I, a fact that has been confirmed by several investigators. Also, Bader (1954) described a bacterium, the $O$ antigens of which were related to those of S. sonnei and assigned the microorganism to the genus Pseudomonas on the basis of its polar monotrichous flagellation. The authors procured this strain (M51) from Dr. Bader in 1955 and demonstrated that its $O$ antigens were identical with those of the original C27 culture of Ferguson and Henderson. Twenty of the above-mentioned $48 \quad \mathrm{C27}$ strains were antigenically related to $\underline{S}$. sonnei, the remainder were not.

In spite of these reports on the polar flagellation of C27 strains, some workers have more or less tacitly accepted them as Enterobacteriaceae, although they have never been assigned to any particular group in that family. As a result of the studies herein reported the authors were convinced that the C27 bacteria do not belong in the family Enterobacteriaceae and that their resemblance to certain members of that family was only superficial. All of the cultures utilized glucose fermentatively in the medium of Hugh and Leifson (1953), and hence should not be placed in the genus Pseudomonas. They differed from described species of Aeromonas in some respects but appeared to be more closely related to members of that group than to any other. Further, studies on the flagellation of C27 strains, kindly made by $\mathrm{Dr}$. Rudolph Hugh of George Wa shington Univer sity, have confirmed the fact that the flagellation of the cultures was predominately polar monotrichous and that the morphology and variation of the flagella was like that of Aeromonas. 


\title{
BACTERIOLOGICAL NOMENCLATURE AND TAXONOMY
}

\begin{abstract}
Summary
The results of the studies reported indicate that the cytochrome oxidase test affords a rapid, convenient, and accurate method for the differentiation of Aeromonas and Aeromonas-like cultures from members of the family Enterobacteriaceae and that the differentiation thus effected can be confirmed by the pattern of reaction obtained in other biochemical tests. Further, the investigations indicate that the differentiation of certain important vibrios, such as Vibrio comma, from the Enterobacteriaceae can be ffected in a similar manner.
\end{abstract}

\section{Addendum}

After this manuscript was prepared, the authors received a reprint of an article entitled Studies on So-called Paracolon C27 (Ferguson) by Sakazaki, R., S. Namioka, R. Nakaya, and H. Fukumi (Japan. J. Med. Sci. Biol. 12: 355 363 ) in which it was concluded that the C27 bacteria should be classified in the genus Pgeudomonas, and in which the name Pseudomonas michigani was proposed. The authors cannot agree that the "C27" bacteria should be 80 classified, since the authors' work has shown that among other. things they are fermentative forms, and probably should be placed in the genus Aeromonas. Further; the specific epithet "shigelloides" (Pseudomonas shigelloides, Bader 1954) may have priority. These matters will bediscussed in detail in a forthcoming publication.

\section{References}

Bader, R.E. 1954. Ueber die Herstellung eines agglutinierenden Serums gegen die Rundform von Shigella sonnei mit einem Stamm der Gattung Pseudomonas. Zeit. f. Hyg. 140: 450-456.

Ferguson, W. W. and N.D. Henderson. 1947. Description of strain C27: a motile organism with the major antigen of Shigella sonnei phase I. J. Bact. 54: 179-181.

Gaby, W.L. and C. Hadley. 1957. Practical laboratory test for the identification of Preudomonas aeruginoes.

J. Bact. 74: 356-358. 
Griffin, P.L. 1952. Some factors influencing pigment production in Bacterium salmonicida. Bact. Proc. p. 53.

S.F. Snieszko and S. B. Friddle. 1953. A new adjuvant in the diagnosis of fish furunculosis caused by Bacterium salmonicida. Veterinary Med. 48: 280-282.

Hugh, R. and $\mathbf{E}$. Leifson. 1953. The taxonomic significance of fermentative versus oxidative metabolism of carbohydrate by various gram negative bacteria. J. Bact. 66: 24-26. 